Milan Marković ${ }^{1}$

University of Niš, Innovation Center
SCIENTIFIC REVIEW ARTICLE

doi:10.5937/ekonomika1903055M

Received: April 19. 2019.

Accepted: Jun, 14. 2019.

\title{
ANALYSIS OF COMPARATIVE ADVANTAGES OF SERBIAN EXPORTS AT THE SECTORAL LEVEL ${ }^{2}$
}

\begin{abstract}
The aim of the paper is to analyze the position and comparative advantages of the export sectors of the Republic of Serbia, using the RCA index, for the period from 2012 to 2017, both in the overall market and at the most important export destinations, such as the EU and the countries signatory to the CEFTA agreement. The research shows that the biggest potential is the "Animal and vegetable oils, fats and wax" sector, as it has the highest comparative advantage. Of the sectors with the largest exports, "Machines and transport devices" are distinguished, which on the CEFTA market has a significant comparative advantage, which is a sector that includes high-tech products and with its exports can significantly contribute to improving the structure of exports. A drastic drop in comparative advantages is recorded in the "Food and living animals" sector, as the largest part of the traditionally important agri-food sector. The analysis used the available databases of the Republic Institute of Statistics of the Republic of Serbia, using standard mathematical and statistical methods.
\end{abstract}

Key words: RCA index, SITC, export sectors, comparative advantages, exports.

Jel classification: F14.

\section{АНАЛИЗА КОМПАРАТИВНИХ ПРЕДНОСТИ СРПСКОГ ИЗВОЗА НА СЕКТОРСКОМ НИВОУ}

\begin{abstract}
Апстракт
Циљ рада јесте анализа позищије и компаративних предности извозних сектора Републике Србије, применом РЦА индекса, за период од 2012. до 2017. године, како на иелокупном тржишту, тако и на најважнијим извозним дестинаичиама као што су ЕУ и земье потписнице ЦЕФТА споразума. Истражсивање показује да највећи потенцијал представља сектор „Животиюска и биљна уља, масти и воскови“", јер има највећу компаративну предност. Од сектора са највишим извозом, издваја се „,Машине и транспортни уређаји“, који на тржишту ЦЕФТА остварује значајну компаративну предност, а ради се о сектору који обухвата високо технолошке производе и својим извозом може битно допринети побољиағу структуре извоза. Драстичан пад компаративних предности бележи сектор „Храна и живе животиње“, као највећи део традиционално важног пољопривредно-прехрамбеног сектора. У анализи су коришћене распо-
\end{abstract}

\footnotetext{
${ }^{1}$ markovicmilan89@gmail.com

${ }^{2}$ Acknowledgements: The paper is a part of the research done within the project number 179066 ("Improving the Competitiveness of the Public and Private Sector by Networking Competences in the European Integration Process of Serbia") financed by the Ministry of Education, Science and Technological Development of the Republic of Serbia.
} 
ложсиве базе података Републичког завода за статистику Републике Србије, уз примену стандардних математичких и статистичких метода.

Кључне речи: РЦА индекс, СМТК, извозни сектори, компаративне предности, извоз.

\section{Introduction}

Parallel to the reduction of trade barriers, which is a practical result of the globalization process, the competitive position of countries in the world markets has become increasingly important in affecting the countries' growth and development prospects (Ekmen-Özçelik \& Güzin, 2014, p. 18). In order to reduce the trade balance deficit, as well as to increase the rate of economic growth, it is necessary to monitor the comparative advantages, both of the overall economy and of its parts. The movement of the trade balance is one of the basic indicators through which the level of competitiveness is perceived (Purić \& Jerotijević, 2015).

A comparative advantage can be analyzed at different levels of observation: at the level of the national economy, economic sectors, branches, commodity groups. In the survey, parts of the economy at the sector level are observed. According to the Standard International Trade Classification (SITC) there are 10 export sectors of the Republic of Serbia, whose comparative advantages will be considered using the RCA (Revealed Comparative Advantage) index. At the macro level, the RCA index shows the success of the economy in the international context and is most often identified with the notion of competitiveness of the national economy exports, because it includes data on foreign trade, which includes indirectly the availability of factors of production, as well as government policy (Branković, 2015).

Such an analysis is also significant from the point of view of changing the production and export structure in order to increase exports, and in particular to increase net exports. The factors that contribute to movements in RCA are economic: structural change, improved world demand and trade specialization (Batra \& Khan, 2005, p. 5).

The aim of the study is to identify the most propulsive sectors of the Serbian economy (compared with foreign countries and the entire economy), as well as those with the highest RCA index, for the EU and CEFTA market, as the most important export markets. The modified version of this index ( $\left.\mathrm{RCA}_{2}\right)$ will be applied for the analysis of comparative advantages in all export sectors, while the so-called "the net export index" $\left(\mathrm{RCA}_{1}\right)$ is used in the analysis of the entire economy (foreign trade).

\section{Methodology}

One of the most useful tools in assessing the comparative advantages of the economy and the export sectors is the RCA index. Since it encompasses international flows, apart from being a measure of the comparative advantage of exports, it can be said that it is an indicator of external competitiveness of the economy. It is often also referred to as the index of net exports, because according to the most commonly used and at the same time the simplest form, it represents the ratio of the balance (surplus or deficit) and the sum of foreign trade exchange of the economy (Jefferson Institute, 2003): 


$$
R C A_{1}=\frac{\left(X_{j}-M_{j}\right)}{\left(X_{j}+M_{j}\right)}
$$

where:

$\mathrm{RCA}_{1}$ - index of comparative advantages of the economy $j$,

$\mathrm{X}_{i}$ - export of the economy $j$,

$\mathrm{M}_{i}-$ importing the economy $j$.

In this way, comparative advantages are seen at the level of the entire economy. The index can range from -1 to +1 . If the index is positive, the economy realizes comparative advantages; otherwise, negative values mean that there are no comparative advantages, i.e. the presence of comparative disadvantages in the international market.

The measurement of competitiveness and comparative advantages based on different theories (Rikardo, Hecksher-Ohlin) creates a number of difficulties that primarily relate to the coverage of a large number of factors of comparative advantage as well as the difficulty of measuring and comparing these factors across countries and sectors (Božić \& Nikolić, 2013, according to: Utkulu \& Seymen, 2004). The RCA index application overcomes many problems in measuring comparative advantages, but the disadvantage is that this index does not show the main sources of these advantages (Božić \& Nikolić, 2013). He was formulated by Balassa in 1965, and has been in use for more than five decades, although he has undergone some modifications. The original formula included only export flows, so it is often disputed for this reason (Greenaway \& Milner, 1993).

$\mathrm{RCA}_{2}$ the index is used in the analysis of comparative advantages at lower levels of observation. The formula to be used in the research includes a sectoral level and includes certain trading partners in the analysis (Balassa, 1965; Utkulu \& Seymen, 2004; Birovljev, Matkovski \& Ćetković, 2015, Božić \& Nikolić, 2013):

$$
R C A_{2}=\frac{\frac{X_{i j}}{X_{t}}}{\frac{M_{j}}{M_{t}}}
$$

where:

$\mathrm{RCA}_{2}$ - index of export comparative advantages of the sector $i$ of the economy $j$,

$\mathrm{X}_{i j}$ - export of the sector $i$ of the economy $j$,

$\mathrm{M}_{i j}$ - import of the sector $i$ of the economy $j$,

$\mathrm{X}_{i t}$ - total exports of all sectors of the economy $j$ to countries $t$,

$\mathrm{M}_{i t}$ - total imports of all sectors of the economy $j$ from countries $t$.

In fact, RCA index of open comparative advantage is the ratio of the relative share of the value of export of sector in total export of the country in a particular market and the relative share of the value of import of sector in the value of total import of a country from that particular market (Božić \& Nikolić, 2013, p. 17). In the literature, this formula is most often used in the consideration of the comparative advantages of the agricultural sector.

In this paper, the $\mathrm{RCA}_{2}$ index will be calculated for all 10 sectors of the economy, according to the Standard International Trade Classification (SITC) of the Republic 
Institute for Statistics of Serbia. According to this classification, they are marked with one-digit numbers, from 0 to 9 , and they are the following sectors:

0 - Food and live animals,

1 - Beverages and tobacco,

2 - Crude materials, inedible, except fuels,

3 - Mineral fuels, lubricants and related materials,

4 - Animal and vegetable oils, fats and waxes,

5 - Chemicals and related products, not elsewhere specified,

6 - Manufactured goods classified chiefly by material,

7 - Machinery and transport equipment,

8 - Miscellaneous manufactured articles,

9 - Commodities n. e. s. in the SITC Rev. 4.

The minimum value of this index is 0 , and in the range 0 to 1 denotes the existence of comparative disadvantages. The higher value of the index indicates that the export sector has more comparative advantages in the international market: if the index is greater than 1, this means that the sector achieves comparative advantages, the index value of over 2 shows significant, and above 3 exceptional comparative advantages. This is a modified RCA index - RCA index, which, unlike the original, includes data on total and sectoral imports. Also, unlike the $\mathrm{RCA}_{1}$ index, it measures the relative export potential, i.e. the comparative advantages of the sector in relation to the total economy.

The research covers a six-year period, from 2012 to 2017.

\section{Results and discussion}

At the beginning of the analysis, the value of the $\mathrm{RCA}_{1}$ index for the entire economy of the Republic of Serbia will be calculated. Based on Chart 1, it can be seen that the net export index has been steadily growing since 2012 (especially in 2013), while a smaller decline was recorded in the last year of the analysis.

Chart 1: RCA index of the Republic of Serbia for the period from 2012 to 2017

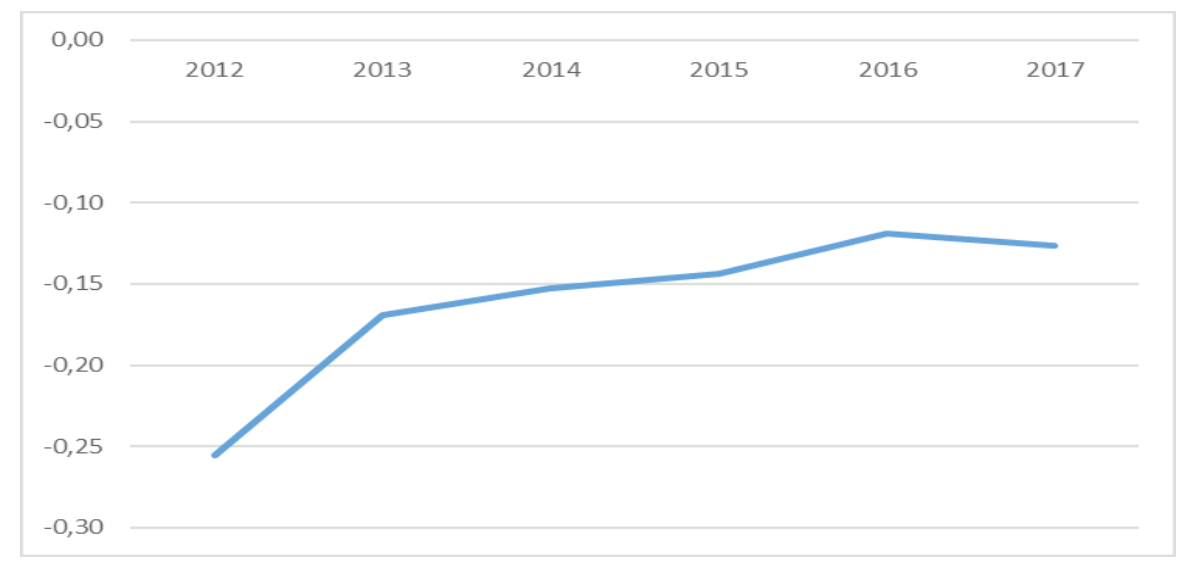

Source: Calculation and presentation of author based on data from the Republic Statistical Office, 2018. 
Looking at the geographical structure of exports, most of the exports (average from 2012 to 2017) go to EU countries - 64\%, 19\% to CEFTA countries, while the rest of $17 \%$ goes to other export destinations.

Chart 2: Geographical structure of exports of the Republic of Serbia

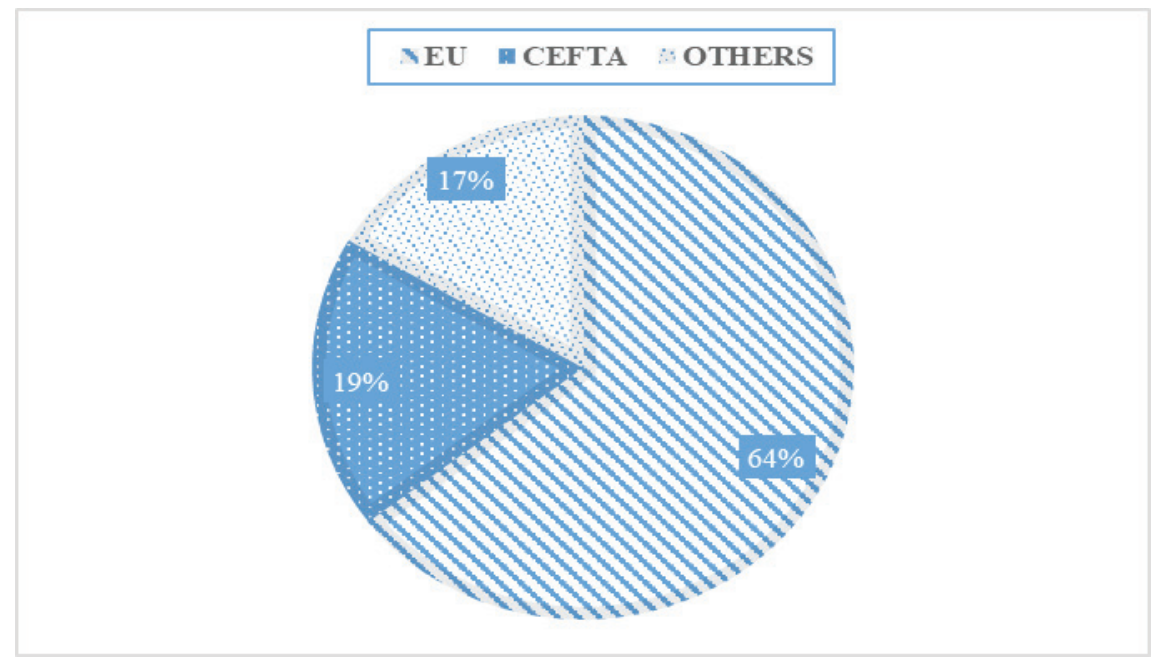

Source: Calculation and presentation of author based on data from the Republic Statistical Office, 2018.

As the EU and CEFTA are the most important Serbian export markets, the RCA index for both markets will be examined according to the Serbian export sectors. Bearing in mind the results of the analysis from Table 1, it is concluded that sector 4, "Animal and vegetable oils, fats and waxes", achieves the highest level (exceptional) of comparative advantages in the foreign market. In particular, the $\mathrm{RCA}_{2}$ index is high (when it comes to this sector) in the CEFTA market. Sector 8, "Miscellaneous manufactured articles", achieves significant comparative advantages in both economic destinations of exports. The solid results are also shown in the sector 0 , which is the main part of the agri-food sector. Except for the sector 9, which recorded a very low share in total exports $(1 \%$ on average), the lowest RCA index on the CEFTA market was recorded in sector 3 , "Mineral fuels, lubricants and related materials", while the EU market is the lowest in the sector 5, "Chemical and related products". This is a very high import dependency of these sectors, because most of the products do not find adequate domestic substitutes (e.g. oil and petroleum products, some chemical products). Generally speaking, the CEFTA market achieves significantly higher comparative advantages in relation to the EU market (according to the calculation of the author 4.19 versus 1.04, the average for the period from 2012 to 2017), due to significantly higher net exports. 
Table 1: RCA index of export sectors of the Republic of Serbia for the EU market and CEFTA

\begin{tabular}{|l|r|r|}
\hline \multirow{2}{*}{ Sectors, SITC, Revision 4 } & \multicolumn{2}{|c|}{ RCA $_{2}, \varnothing(2012-2017)$} \\
\cline { 2 - 3 } & EU & \multicolumn{1}{|c|}{ CEFTA } \\
\hline 0 - Food and live animals & 2,24 & 1,57 \\
\hline 1 - Beverages and tobacco & 0,96 & 1,45 \\
\hline 2 - Crude materials, inedible, except fuels & 1,64 & 0,40 \\
\hline 3 - Mineral fuels, lubricants and related materials & 0,51 & 15,64 \\
\hline 4 - Animal and vegetable oils, fats and waxes & 3,63 & 1,43 \\
\hline $\begin{array}{l}\text { 5 - Chemicals and related products, not elsewhere } \\
\text { specified }\end{array}$ & 0,43 & 0,65 \\
\hline 6 - Manufactured goods classified chiefly by material & 1,11 & 2,29 \\
\hline 7 - Machinery and transport equipment & 1,16 & 2,10 \\
\hline 8 - Miscellaneous manufactured articles & 2,15 & 0,07 \\
\hline 9 - Commodities n. e. s. in the SITC Rev. 4. & 0,02 & \\
\hline
\end{tabular}

Source: Author's calculation based on data from the Republic Statistical Office, 2018.

According to Chart 3, the export structure of the Serbian economy is such that the largest average share is realized by sectors 6 and 7, which together account for half of the total export value. Starting from 2013, export of sector 7, "Machinery and transport equipment", exceeds the export of manufactured goods, mostly due to the export of road vehicles. This is a basic tendency when considering the participation of the sector in the total value of exports of the Republic of Serbia from a temporal aspect.

\section{Chart 3: Structure of the Republic of Serbia exports by sector}

(average 2012-2017)

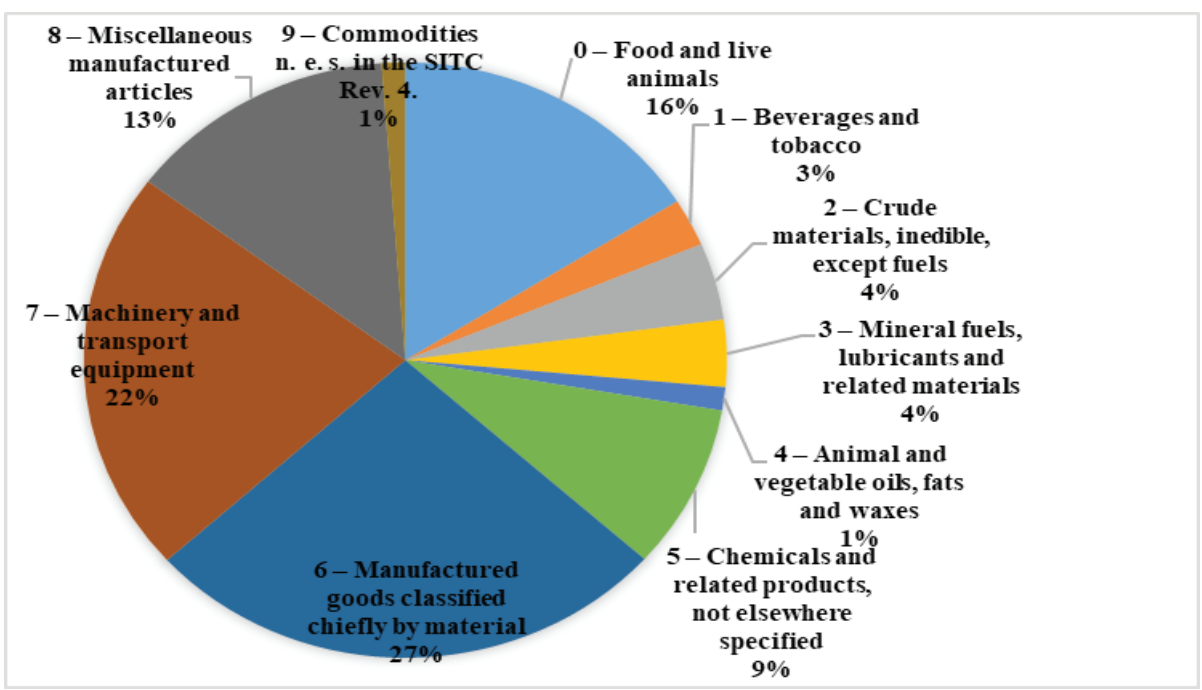

Source: Calculation and presentation of author based on data from the Republic Statistical Office, 2018.

Since sectors 6 and 7 are absolutely dominant, it is necessary to take a closer look at the movement of the $\mathrm{RCA}_{2}$ index in these sectors. In addition to these, the sectors 0 
and 8 fall into the, so-called, export-oriented sectors of the economy of the Republic of Serbia.

Based on the following chart, where we see four sectors with the highest export in Serbia's most important export market, it can be noted that the $\mathrm{RCA}_{2}$ index of the "Miscellaneous manufactured articles" sector in the last year of the analysis is the highest, which means that it is a sector that should be significantly encouraged. The negative fact is that the "Food and live animals" sector in the EU market, in the observed years, "lost" significant comparative advantages. The other two sectors, 6 and 7, have an index slightly above 1 on the EU market, but the sector 7 having a mild tendency of growing. The results show that the mentioned sectors, except sector 0 , recorded growth in relation to the initial value of the $\mathrm{RCA}_{2}$ index in 2012. Tendencies on the CEFTA market, also for the most important export sectors, are shown in Chart 5. "Machinery and transport equipment" have exceptional comparative advantages, starting from 2016, which can contribute to the transformation of the economic structure. This is a very positive fact, since this sector is currently the highest value of imports in the Republic of Serbia, but also with the highest share in the export of the Republic of Serbia. Unlike sectors 0 and 5, whose $\mathrm{RCA}_{2}$ index values are constantly greater than 1, sector 6, "Manufactured goods classified chiefly by material", achieves a comparative disadvantage that should be overcome by an adequate economic policy.

Chart 4: The $\mathrm{RCA}_{2}$ index trends in the most important export sectors in the EU market

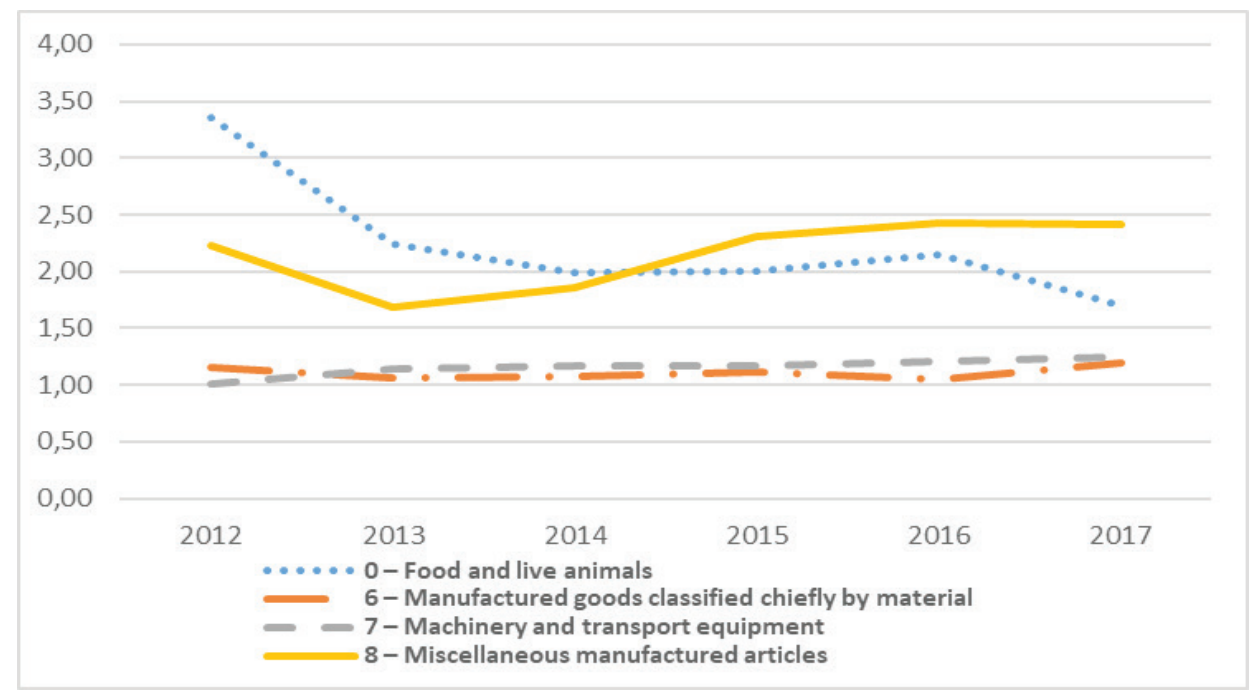

Source: Calculation and presentation of author based on data from the Republic Statistical Office, 2018. 
Chart 5: The RCA, index trends in the most important export sectors in the CEFTA market

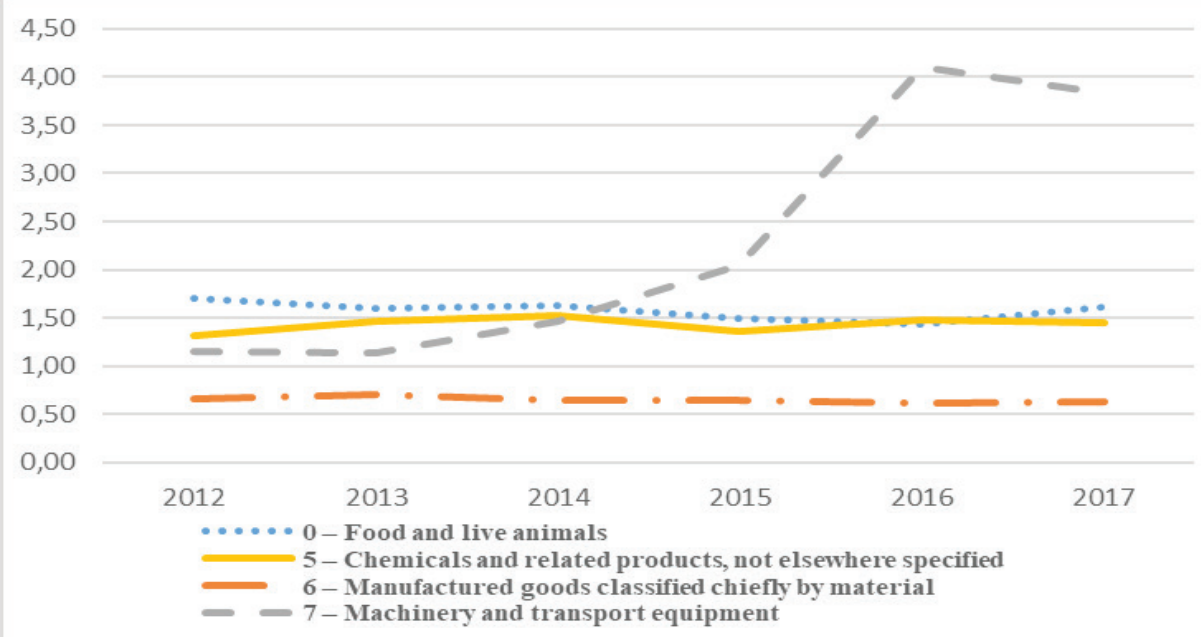

Source: Calculation and presentation of author based on data from the Republic Statistical Office, 2018.

Table 2 gives an analysis of the $\mathrm{RCA}_{2}$ index for the export sectors that have significant comparative advantages, or where this index is greater than 2 . The basic observation is that Sector 4, as the sector with the maximum $\mathrm{RCA}_{2}$ index, achieves an increasingly comparative advantage from year to year. In addition, this sector, in both markets in observed years, is in the group of sectors with significant comparative advantages. The negative fact is that there is a trend in the EU market to reduce the participation of the sector with a positive $\mathrm{RCA}_{2}$ index in Serbia's total exports. The rest of the tendencies, as well as the minimum and maximum values and the value of the median of the $\mathrm{RCA}_{2}$ index, can be seen in Table 2 .

Table 2: Overview of the Serbian export sectors, which have significant comparative advantages on the foreign market according to certain characteristics

\begin{tabular}{|c|c|c|c|c|c|}
\hline & \multicolumn{2}{|c|}{ EU } & \multicolumn{2}{|c|}{ CEFTA } \\
\hline & & 2012. & 2017. & 2012. & 2017. \\
\hline \multirow{3}{*}{$\begin{array}{l}\text { Sectors } \\
\text { where } \mathrm{RCA}_{2} \\
>2\end{array}$} & $\begin{array}{l}\text { Number of } \\
\text { sectors }\end{array}$ & 4 & 2 & 2 & 2 \\
\hline & Sector codes & $0,2,4,8$ & 4,8 & 4,8 & 4,7 \\
\hline & $\begin{array}{l}\text { Participation in } \\
\text { total exports }\end{array}$ & $38,75 \%$ & $14,90 \%$ & $15,23 \%$ & $16,77 \%$ \\
\hline \multicolumn{2}{|l|}{ Min } & 0,06 & 0,02 & 0,08 & 0,16 \\
\hline \multicolumn{2}{|l|}{$\operatorname{Max}$} & 5,07 & 2,41 & 15,50 & 52,61 \\
\hline \multicolumn{2}{|l|}{ Median } & 1,24 & 1,19 & 1,23 & 1,47 \\
\hline
\end{tabular}

Source: Author's calculations 


\section{Conclusion}

A comparative advantage is the ability of the country to take adequate participation in the foreign market. It is generally estimated based on the value of exports in the specific market. The aim of this paper was to identify the most important sectors of the Serbian economy from the point of view of the $\mathrm{RCA}_{2}$ index, as a tool applied in the study.

The basic problem of the research was the consideration of the export comparative advantages of the economy of the Republic of Serbia, and especially its parts - sectors. The analysis was conducted for all exports, as well as for the most important export markets such as the EU and CEFTA. These are groups of countries where $83 \%$ of total exports are sold.

The RCA index for the entire economy was growing until 2017, when a decline was recorded. However, it is still in the zone of negative values, which speaks of the absence of comparative advantages of the Serbian economy as a whole. Sector 4, "Animal and vegetable oils, fats and waxes", have the highest comparative advantages in the foreign market, so this should be used because this sector accounts for only $1 \%$ of total exports.

Sectors 6 and 7 occupy the largest share in the structure of exports. However, sector 6, "Manufactured goods classified chiefly by material", and on the EU and CEFTA markets, does not achieve significant comparative advantages, while sector 7 , "Machinery and transport equipment", on the CEFTA market has recorded significant comparative advantages, thus representing an exceptional export potential in this market. This is particularly important, because it is a sector that consists of products with a higher unit export price and which can influence strong industrial and economic development.

The negative fact is that there is a constant decline in the comparative advantages of the sector 0 , "Food and live animals," so that by 2017, it ceases to achieve significant comparative advantages in the international market. In addition, in the EU market, the situation is such that the RCA index worsens. Compared to 2012, in 2017, sectors with significant comparative advantages account for only $14.90 \%$ of total exports - a decrease of almost 24 percentage points. A constant level of comparative advantage is observed in the CEFTA market.

In order to further increase the RCA index, it is necessary to reduce the import dependence on oil derivatives and inputs used in the automotive industry, while economic policy makers should support the agricultural sector more significantly (especially the production of beverages and tobacco), which, along with the IT sector, can be a key factor in increasing the net export.

\section{References}

Balassa, B. (1965). Trade liberalization and revealed comparative advantage. Manchester: The Manchester School of Economics and Social Studies Journal, 33(2), 99-123.

Batra, A., \& Khan, Z. (2005). Revealed comparative advantage: An analysis for India and China, No. 168. Working paper.

Birovljev, J., Matkovski, B., \& Ćetković, B. (2015). The competitiveness of the Serbian agri-food products on the market of countries in the region. Anali Ekonomskog fakulteta u Subotici, (33), 61-78. 
Božić, D., \& Nikolić, M. (2013). Significance and comparative advantage of the agrarian sector in Serbian foreign trade. Agriculture and Rural Development - Challenges of Transition and Integration, Book of Proceedings (pp. 13-31). Belgrade: Faculty of Agriculture, University of Belgrade.

Branković, A. (2015). Извозна конкурентност привреде Републике Србије под утицајем транзиционих промена [Ехрогt competitiveness of the economy of the Republic of Serbia under the influence of transitional changes]. Available at: http://ebooks.ien.bg.ac.rs/11/

Ekmen-Özçelik, S., \& Güzin, E. (2014). Turkey’s Comparative Advantages and Dynamic Market Positioning in the EU Market. Emerging Markets Finance \& Trade, 50(5), 18-41. https://doi.org/10.2753/REE1540-496X500502

Greenaway D., \& C. Milner (1993). Trade and Industrial Policy in Developing Countries: A Manual of Policy Analysis. The Macmillan Press, esp. Part IV Evaluating Comparative Advantage, (pp. 181-208).

Jefferson Institute (2003). Konkurentnost privrede Srbije [Competitiveness of the Serbian economy]. Beograd.

Purić, S., \& Jerotijević, D. (2015). The structure of exports and imports as a limiting factor in improving the competitiveness of the Republic of Serbia. Ekonomika, 61(3), 121-132.

Republic Statistical Office (2018). Available at: http://data.stat.gov.rs/Home/ Result/170301?languageCode=sr-Cyrl\# Retrieved: 22/12/2018.

Utkulu, U., \& Seymen, D. (2004). Revealed Comparative Advantage and Competitiveness: Evidence for Turkey vis-à-vis the EU/15. In European trade study group 6th annual conference, ETSG (pp. 1-26). 